\title{
Historical changes on the fisheries management in Cambodia
}

\author{
Satoshi Ishikawa ${ }^{1, *}$, Mina $\mathrm{HoRI}^{2}$, Akira TaKagI ${ }^{2}$, Thuok $\mathrm{NaO}^{3}$, Kazuhiro Enomoto ${ }^{2}$ and Hisashi \\ KUROKURA ${ }^{2}$ \\ ${ }^{1}$ Department of Fishery, School of Marine Science and Technology, Tokai University, Sizuoka, 424-0886, Japan \\ ${ }^{2}$ Department of Global Agricultural Sciences, Graduate School of Agricultural and Life Sciences, The University of Tokyo, Tokyo 113-8657, Japan \\ ${ }^{3}$ Department of Fisheries, Ministry of Agriculture, Forestry and Fisheries, No.186, Norodom Blvd, Sangkat, Tonle Bassac, Khan Chamcarmon, \\ PO.box 582, Phnom Penh, Kingdom of Cambodia \\ ${ }^{*}$ Corresponding author, Tel; 054-334-0411, E-mail; oounagi@hotmail.com
}

\begin{abstract}
Cambodia has rich aquatic resources particularly favored from the Mekong River Basin and Tonle Sap Lake. Fisheries activities have been conducted since ancient times. Until the eighteenth century, any people regardless of nationality and occupation could conduct fishing and obtain fishery products from freshwater areas in Cambodia. At present, freshwater fisheries are still important for food security of Cambodian people, as clearly shown by the fact that approximate
\end{abstract} $\mathbf{7 5 \%}$ of protein intakes are supplied from freshwater fisheries products. However, contemporary circumstances surrounding fisheries have come to be quite different from those before. For instance, several fish species are listed as endangered while over exploitation of fishery resources has been criticized as environmentally hazardous and bringing about resource depletion by international communities. At the same time, conflicts between fishermen and among relevant stakeholders have been prevailing in various parts of the country. After the last civil war, Cambodian government has been financially supported by foreign countries for the economic development. In this regard, Cambodia should seek for an appropriate policy to enable both the management of national living resources including fishery resources and public security simultaneously, in favor of international consensus.

Key Words: Cambodia, fisheries management, conservation, community- based resource management

\section{INTRODUCTION}

Cambodia is located in the middle part of Indochina and holds rich aquatic resources particularly deriving from the Mekong River Basin and Tonle Sap Lake, which nurture abundant fish recourses (Fig. 1). Zhou Daguan who had visited to Angkor Wat City from 1296-1297,

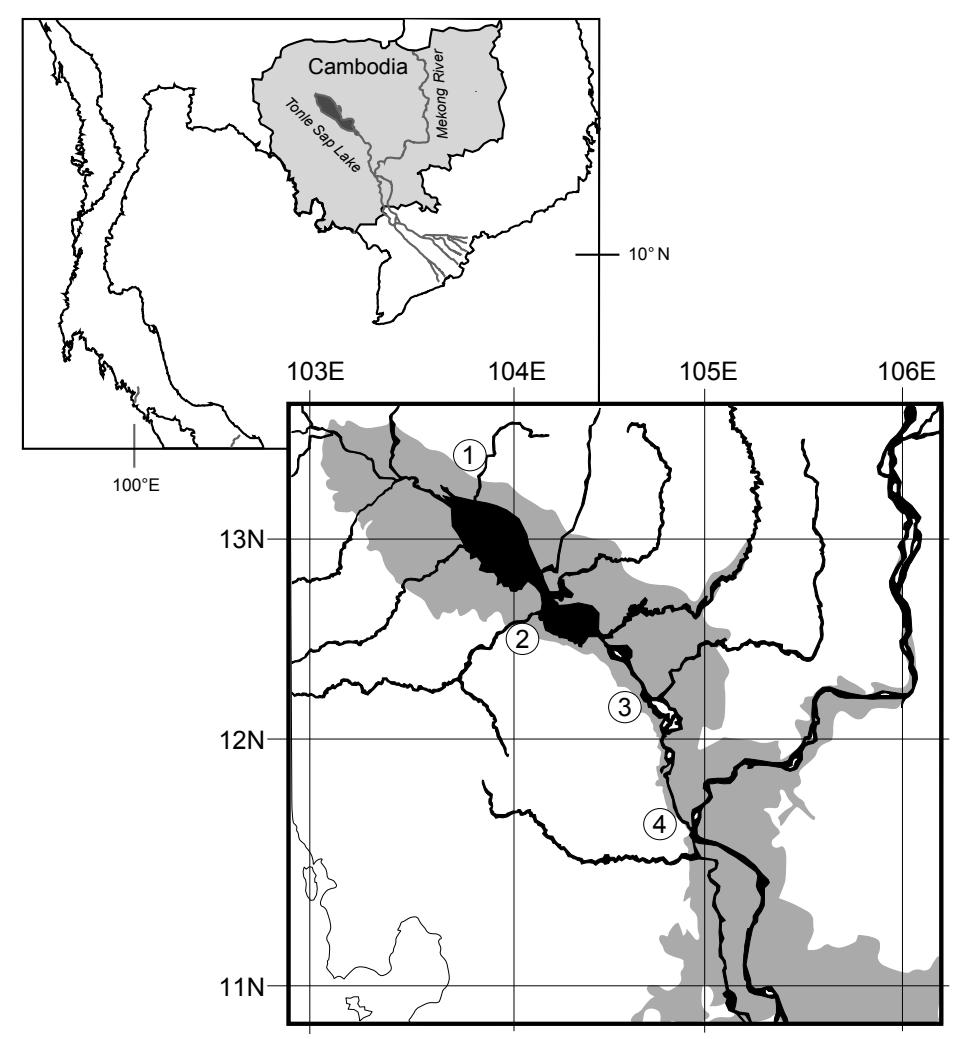

Fig. 1. Map of Kingdom of Cambodia. Black lines indicate rivers and gray areas show the flooding area in the rainy season. Numerals within circles indicate the position of historical Capital cities, 1; Siem Reap, 2; Pursaat, 3; Kompong Chhnang, 4; Phnom Penh. 

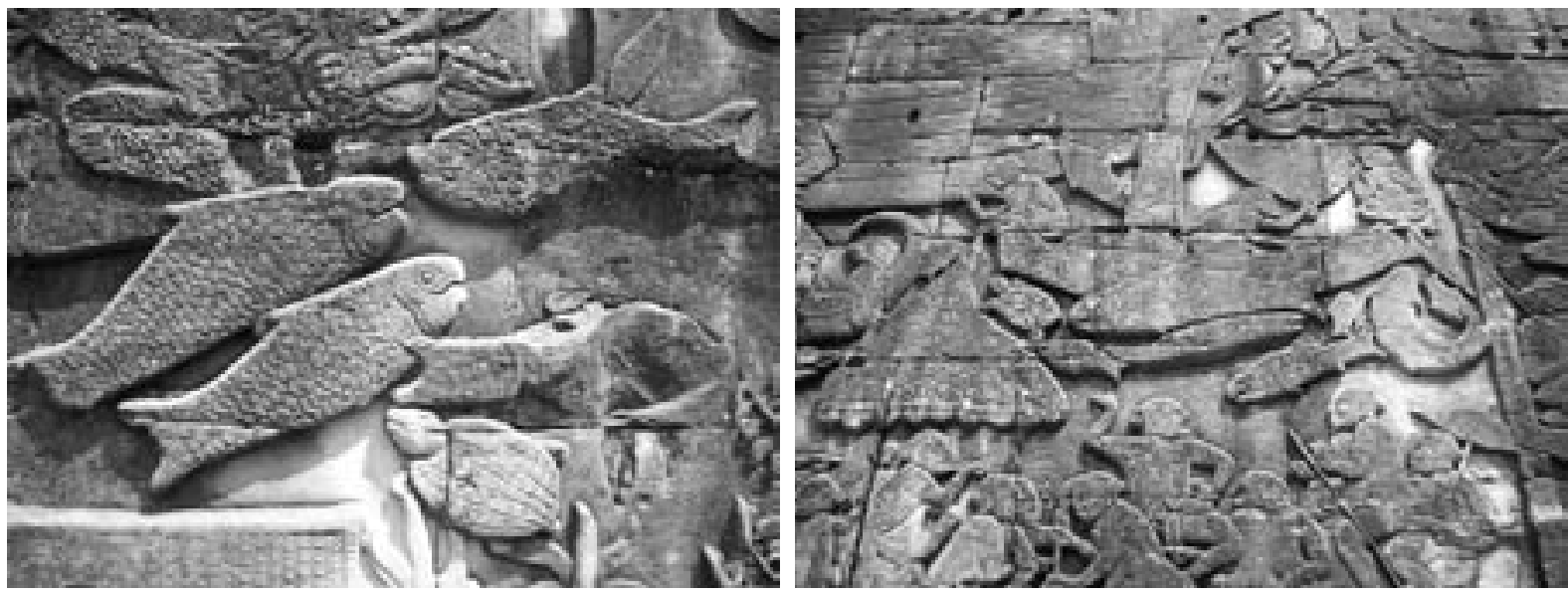

Fig. 2. Photos of carvings of fish and fishermen on the walls of the ancient Angkor

described an impression of the fish abundance and the huge size of Tonle Sap Lake. A French traveler named Henri Mouhot (1826-61) also described a large quantity of fish in Tonle Sap Lake. Based on the abundant fish resources, inland fisheries have played a quite important role for the livelihood of rural people since ancient times in Cambodia. Fisheries productions have been recognized as the second important food after rice in the daily diet for Cambodian people. A number of relief of fish and fishermen engraved on the walls of the ancient Angkor Tom temple told a deep involvement between people and fish (Fig. 2). This paper aims to overview historical changes on the fisheries management in Cambodia, particularly focusing on fisheries in Tonle Sap Lake that cover a large part of inland fisheries production in Cambodia.

\section{METHODS}

Historical documents and the government fisheries statistics are used to describe historical changes of fisheries management and to analyze inland fisheries management scheme and regulations over these hundreds of years. Interviews to the government fisheries officers as well as local fishermen were conducted to confirm the results of our study.

\section{RESULTS}

Fisheries management before the Independence ( 1953)

Documentary evidence shows the first fisheries management in Cambodia was conducted by King Norodom (1859-1897) and his predecessors. In this system, formal and informal arrangements were likely to be enacted in order to govern the access to fishing opportunities. This regulatory scheme initially aimed to collect tax for revenue through selling of fishing rights (Mckenny and Tola, 2002; Sina, 2004). Due to a huge abundance of fish, there was no need to conduct resource managements. Besides, during the Angkor era, almost all people of ethnic Khmer conducted rice farming and lived in monastic life style (Mouhot, 1868). At that time, the fisheries managements would not be a great concern for the Khmer people. On the other hand, Chinese and Muslim immigrants from Malay Archipelago controlled commercial fishing with the concessions issued by King and fish trade during this period (Ear, 1995).

In early $19^{\text {th }}$ century, France military forces invaded into Indochina, and Cambodia became the protectorate of France in 1863 (Table 1). During the French colonial period, commercial fishing around Tonle Sap Lake was conducted by the rich Chinese merchants who obtained the fishing concession rights and they employed a large number of Vietnamese laborers for both fishing and fish processing. Fish products such as fish paste and smoked fish were supplied to local markets in Cambodia while salt-dried fish were mainly exported to Singapore and Hong Kong. The commercial tax occupied major part of the revenue of Cambodia.

In 1908, fishery laws and regulations were enacted following French colonial systems in order to generate revenue (Table 1) (Bruce et al. 2002). To facilitate tax collection, the fishing lot system was invented by the French experts in 1929 (Mak, 2000), and implemented in 1940 (Thay, 2002) (Table 1, Fig. 3). Around the same time, commercial fish yields were observed to decline since after 1935. Depletion of fishery resources was feared. 
Table 1. Chronological table of fisheries managements in Cambodia after 1863.

\begin{tabular}{|c|c|}
\hline Year & Domestic affairs \\
\hline $\begin{array}{l}\text { Until } 15^{\text {th }} \\
\text { century }\end{array}$ & $\begin{array}{l}\text { The king of Angkor could issue fishing concession to investors and traders, the fishing } \\
\text { concession could be subleased to fishers. }\end{array}$ \\
\hline 1863 & Cambodia became France's protectorate \\
\hline 1872 & Begin commercial fisheries in Cambodia* 1 \\
\hline 1908 & Fishing law and regulations were published \\
\hline 1920 & Fishing period was settled ${ }^{*} 2$ \\
\hline 1929 & Fishing Lot systems was devised by a French expert \\
\hline 1940 & Lot system was adopted \\
\hline 1953 & Independent from France \\
\hline 1956 & Old fishing law was adopted \\
\hline $1970-1975$ & Many fishing lots were occupied by rebel armies of Vietnam War \\
\hline $1975-1979$ & $\begin{array}{l}\text { The Pol Pot Regime. Commercial fishing was abandoned, and fishing activities by local } \\
\text { authorities were carried out. }\end{array}$ \\
\hline 1979-1982 & $\begin{array}{l}\text { Occupied by Vietnam troops. No commercial fishing and no fishing regulation. Vietnamese } \\
\text { fishermen immigrated into Cambodia. }\end{array}$ \\
\hline $1982-1989$ & Commercial fisheries were conducted by the solidarity groups named Krom Samaki. \\
\hline 1989 & $\begin{array}{l}\text { Fishing law was modified. Fishing areas were privatized and commercial fisheries were } \\
\text { conducted by license owners (so called Lot owner). }\end{array}$ \\
\hline 1993 & National election was taken place and new Cambodian government was established \\
\hline 1999 & Many conflict between Lot owners and local fishermen was reported \\
\hline 2000 & $\begin{array}{l}\text { Reform of the fishing management system. } 56 \% \text { of Lot area were released from lot owners to } \\
\text { local fishing communities }\end{array}$ \\
\hline 2001 & Community Fisheries Development Office (CFDO) was established \\
\hline
\end{tabular}

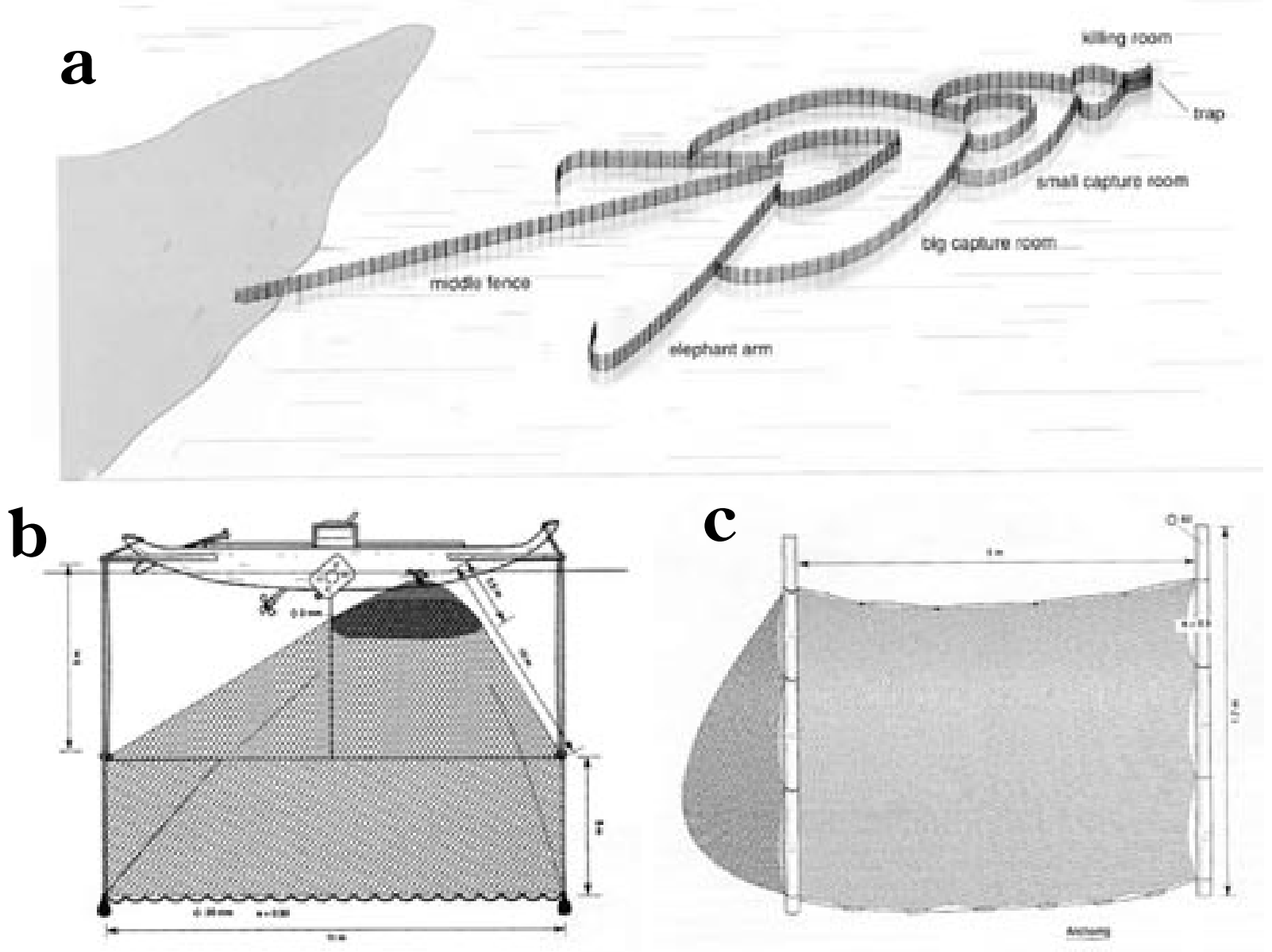

Fig. 3. Illustrations of the typical fishing gears of three fishing categories drew in Degen and van Zalinge 2003. a) an arrow shape bamboo fence used in the Large scale fishery, b) a deep bag net used in the Middle scale fishery, c) a hand dragged seine net used in the Small scale fishery. 
Fishery management after Independence (1953 2003)

After independent of France, fisheries law was promulgated in 1956 by Department of Fisheries (Table 1 ). In the promulgated fisheries law, property rights of the state on overall land and marine waters were proclaimed. And Inland water bodies were divided into three categories in accordance with intended use of fisheries: commercial fisheries area (Fishing lot), middle and small scale fisheries area (open access), and the biological conservation area (fish sanctuary) (Tana, 1998). It is suggested that conservation and management of fish resources would be already considered in this regime.

In the late 1960s, Cambodian land and people were embrangled into Vietnam War. As some rebel armies occupied many part of the fishing lots, fisheries management in Cambodia met serious difficulties. After Vietnam War, Khmer Rouge (Pol Pot) governed the state with supports from China. The Pol Pot regime focused on rice production, and any commercial fisheries activities were abandoned. In 1979, another communist government structured was established by Vietnam supports. And a large number of Vietnamese fishermen immigrated into Cambodian fishing grounds (Amakawa, 2004; Sina, 2004). From 1982 to 1989, commercial fisheries were controlled by solidarity groups named Krom Samaki which formed by the communist regime. However, almost all fisheries businesses failed due to a lack of knowledge and skills for both resource management and fishing activities (Sina, 2004).

In 1989, Vietnamese troops left Cambodia and representative of eighteen countries, four Cambodian parties and secretary general of the United Nations met in Paris to negotiate a comprehensive settlement of
Cambodian civil war. And the comprehensive settlement was agreed in 1990. The basic fisheries law was modified and upgraded to be a Fiat Law 33 which was promulgated partly in 1987 and fully in 1989 (Sina, 2004). According to this law, inland fisheries were divided into three categories: Large, Middle and Small scale fisheries (Tables 2, 3). The Large scale fishery is a license-based commercial activity. People who conduct this fishery should purchase the fishing license and holds exclusive fishing rights for two years. License-based fishery is mainly composed of Lot fishery and Dai fishery. The Middle scale fishery is also license-based commercial activity. People who operate this fishery should register fishing gears to the government for fishing license every two years. The Small scale fishery is regarded as subsistent activity. Everyone can conduct the Small scale fishery in any fishing ground. Putative spawning period of many fish species from June to September in north area of Chaktomuk and from July to October in south area of Chaktomuk is treated as closing season for the Large and Middle scale fisheries.

Under the new fishing law, the people who purchase the fishing license (Lot owner) hold exclusive fishing right in the Lot area, but everyone is permitted to conduct small scale fishery in anywhere even in the Lot area during the closing season ( $1^{\text {st }}$ June to $30^{\text {th }}$ September). This inconsistency of the fishing rights caused conflicts between Lot owners and local people. And a number of the conflicts increased as the Small scale fishermen increased. The fisheries conflict has come to be a main political issue in 1999 (Table 4). Then, the government changed 73 Lot areas (56\% of total Lot area in width) to open access fishing ground as a countermeasure for the fisheries conflicts in 1999. This prompt countermeasure took good effect to decrease number of the conflicts and

\section{Table 2. Range of the annual inland fish catch from 1994-1998}

\begin{tabular}{|c|c|c|}
\hline Types of fisheries & $\begin{array}{l}\text { Annual fish catch } \\
\text { in tons }\end{array}$ & Concessions \\
\hline $\begin{array}{l}\text { Large scale fisheries } \\
\text { - Fishing Lots } \\
\text { - Dai (bag nets) }\end{array}$ & $\begin{array}{l}30,000-60,000 \\
15,000-20,000\end{array}$ & $\begin{array}{l}\text { Licensed commercial fishery using large fence traps and bag nets } \\
\text { which are operated by more than ten fishermen. }\end{array}$ \\
\hline Middle scale fisheries & $85,000-100,000$ & $\begin{array}{l}\text { Regulated commercial fishery using seine and gill nets which are } \\
\text { operated by } 2-3 \text { persons. }\end{array}$ \\
\hline $\begin{array}{l}\text { Small scale fisheries } \\
\text { - Family fisheries } \\
\text { - Rice field fisheries }\end{array}$ & $\begin{array}{r}115,000-140,000 \\
45,000-110,000\end{array}$ & $\begin{array}{l}\text { Substantial fisheries without any registrations or concessions using } \\
\text { small traps and nets. }\end{array}$ \\
\hline
\end{tabular}

Source: Deap et al. (1998) and Ahmed et al. (1998) 
Table 3. Kinds of fishing gears of three types of fisheries in Cambodia

\begin{tabular}{|c|c|}
\hline Types of fisheries & Fishing gears names \\
\hline \multirow[t]{4}{*}{ Large scale fishery } & Bamboo fence \\
\hline & Fish bag net (DAI) \\
\hline & Shrimp bag net (DAI) \\
\hline & Arrow shape bamboo fence \\
\hline \multirow[t]{11}{*}{ Middle scale fishery } & Gillnet \\
\hline & Seine net \\
\hline & Deep bag net \\
\hline & V shape net \\
\hline & Big cone-shaped net \\
\hline & Raft mounted lift net \\
\hline & Scooping net \\
\hline & Vertical vase trap \\
\hline & Cylindrical drum trap \\
\hline & Bamboo fence trap \\
\hline & Hooked long line \\
\hline \multirow[t]{16}{*}{ Small scale fishery } & Gillnet (shorter than 10m length) \\
\hline & Cast net \\
\hline & Oblong trap \\
\hline & Cylindrical drum trap \\
\hline & Small vertical slit trap \\
\hline & Handle scooping basket \\
\hline & Scooping net (diameter of mouth $<2 \mathrm{~m}$ ) \\
\hline & Drop-door trap \\
\hline & Folded woven trap \\
\hline & Raft mounted lift net \\
\hline & Fork harpoon \\
\hline & Spear \\
\hline & Shape forked spear \\
\hline & Bamboo pieced-eel trap \\
\hline & Rice-field small bag trap \\
\hline & Funnel trap \\
\hline
\end{tabular}

Source: Sina 2004.

Table 4. Numbers of fishing lot, widths of lot areas and numbers of conflicts.

\begin{tabular}{lccc}
\hline Year & $\begin{array}{c}\text { Number of } \\
\text { fishing lots }\end{array}$ & $\begin{array}{c}\text { Total widths of } \\
\text { lot areas (ha) }\end{array}$ & $\begin{array}{c}\text { Number of } \\
\text { Conflicts }\end{array}$ \\
\hline 1998 & 164 & NA & 826 \\
1999 & 155 & 953,740 & 1990 \\
2000 & 83 & 422,203 & 1258 \\
2001 & 82 & 422,203 & 493 \\
\hline
\end{tabular}

Source: DoF, 2002 Cambodian Fisheries Annual Report

the number of fisheries conflicts was 493 in 2001 (Table 4).

However, the increase of open access fishing areas seemed to facilitate illegal, unreported and unregulated fishing (IUU), and alternative measures for fishing management was required from foreign governmental and non-governmental organizations. Then, Cambodian government decided to implement community-based resource management and community fisheries development office (CFDO) was established in 2001 (Thay, 2002). CFDO has promoted to set up fishing communities for both resource managements and improvement of livelihood of local villagers. By end of 2003, 270 fishing communities were established (Thay, 2002).

Transition of international consensus on environmental conservation and property rights of natural resources

In early $20^{\text {th }}$ century, many nations declared national claims on mineral recourses. And in 1945, the United State President Truman proclaimed his nation's control of the natural resources of the continental shelf and coastal fisheries resources in the high sea. After Truman's proclamation, other nations emulated the United State, and extended their territorial seas to 12 nautical miles and their sovereign rights to a 200 nautical miles (Table 5). A property right of natural resources including aquatic animal resources came to be recognized in international society.

On the other hand, importance of environmental conservation became to be internationally realized. The Ramsal Convention treating conservation issues on wetland was signed in 1971 and subsequently UNEP was established for harmonizing development and conservation in 1972 (Table 5). The club of Roma struck a note of warning against reckless development and exploitation of natural resources on his publication named "The limits to growth”. International consensus shifted toward conservation and regulation of commercial trades of endanger species was recognized (Table 5).

In 1992, earth summit of the United Nations was held in Rio de Janeiro and Agenda 21 was set up as a blueprint for action for sustainable developments in the $21^{\text {st }}$ century. Connecting this event, Food and Agricultural organization (FAO) adopted code of conduct for responsible fisheries for promoting right based and regulated fisheries (FAO, 1995). Then, international plan of action to prevent, deter and eliminate illegal, unreported and unregulated 
Table 5. International events relating environmental conservation and resource management

\begin{tabular}{|c|c|}
\hline Year & Events \\
\hline 1945 & Truman US President proclaimed the property rights of the natural resources in the continental shelf area. \\
\hline 1958 & $\begin{array}{l}\text { The first United Nations Conference of Law of the Sea (UNCLOS) was held. Property rights of natural resources } \\
\text { including living resources in the continental shelf were admitted. }\end{array}$ \\
\hline 1971 & $\begin{array}{l}\text { Conservation on Wetlands of International Importance especially as Waterfowl Habitat (The Ramsal Convention } \\
\text { on Wetland) was signed. }\end{array}$ \\
\hline 1972 & $\begin{array}{l}\text { United Nations Conference on the Human Environment was held. } \\
\text { The UNEP (United Nation Environment Programme) was formed. } \\
\text { The Limits to Growth was published by The club of Roma. }\end{array}$ \\
\hline 1973 & Conservation on International Trade in Endangered Speceis of Wild Fauna and Flora (CITES) was signed. \\
\hline 1982 & $\begin{array}{l}\text { Special Session of the United Nations General Assembly (Nairobi Conference) was held. } \\
\text { The Exclusive Economic Zone (EEZ) was adopted at United Nations Convention of the Law of the Sea. }\end{array}$ \\
\hline 1984 & World Commission on Environment and Development (WCED) was formed. \\
\hline 1987 & The concept of sustainable development was proposed by WCED. \\
\hline 1992 & $\begin{array}{l}\text { Earth Summit the United Nations Conference on Environment and Development (UNCED), was held in Rio de } \\
\text { Janeiro in Brazil. Agenda } 21 \text { was set out as a blueprint for action for the } 21 \text { st century. } \\
\text { The United Nations Commission on Sustainable Development (CSD) was established by the UN General } \\
\text { Assembly }\end{array}$ \\
\hline 1993 & Convention on Biological Diversity (CBD) was concluded. \\
\hline 1995 & Code of Conduct for responsible fisheries was adopted by FAO \\
\hline 2001 & $\begin{array}{l}\text { International Plan of Action to prevent, deter and eliminate illegal, unreported and unregulated fishing was } \\
\text { adopted by FAO councils. }\end{array}$ \\
\hline
\end{tabular}

fishing was adopted by FAO councils in 2001 (Table 5). World consensus moved to restrict open access to natural resources.

\section{Present fisheries managements}

In Cambodia, maintenance of public order and security has the highest priority in political issues. Therefore, the Lot area had been changed to open access fishing area as a countermeasure against fishing conflicts, in spite this action accompany decrease revenue from fishing sector. However, increase of open access fishing area was held in disrepute in nations supporting Cambodian reconstruction. Approximate $30 \%$ of Cambodia governmental expenditure is supported by foreign financing and opinions of donor countries bear on Cambodian politics. Fisheries management based on stock estimation through fisheries statistics analyses would not be appropriate and have low feasibility in this country, due to no data collection systems and high costs for implementation of statistical data collection. Thus, community based resource management would be the only applicable way for fisheries management in Cambodia.

Other two reasons would lie on a background of adopting community-based fisheries management. One is that Cambodia fisheries hold multi-gear and multi-species characteristic. This characteristic makes application of a surplus production model like MSY model for Cambodian fisheries impossible. Because surplus production model request data which are collected and sorted by species and by gears.

Another reason is a shift of main target fishing category for conservation. After the household survey conducted by MRC (Ahmed et al. 1998), main target fishing category for sustainable fisheries development shifted from the Large and Middle scale fisheries to the Small scale fishery, because approximate $70 \%$ of inland fisheries yield are caught by the Small scale fishery (DOF, 2002). Yield of the Small scale fishery is approximate twice of those of the Large and Middle scale fisheries. However, no license and no regulation are required for the Small scale fishery. Cambodia government has no power to control and collect exact data regarding the Small scale fishery. Establishment fishing communities and forming fishermen network are necessary for future data collection of the Small scale fishery.

\section{DISCUSSION}

Further problem for fisheries resourses managements

Fisheries management in Cambodia based on fishing 
communities has been showing results, especially in reduction of fisheries conflicts. However, several serious matters regarding fisheries management are left behind of the current management approach.

One of the left issues is IUU fishing by foreigners. During the period when Cambodia was occupied by Vietnam troops (1979-1982) and subsequent regime of communist government (1982-1989), many Vietnamese people immigrated into Cambodia and they had been conducting fishing. Some of the Vietnamese fishing are reported or regulated under Cambodian policies, but many of them are IUU fishing. One fishing community in Seam Reap province is composed of five Khmer villages and one Vietnamese village. And there are no personal exchanges between Khmer and Vietnamese villagers. And many Vietnamese people operate fishing around Tonle Sap Lake and many of them are not reported. This foreigners fishing is serious problem for eradication of IUU fishing.

Second issue is a farmers fishing. Since fishing community forming is focusing on fishermen, farmers villages are not involved in the community based fisheries management. However, as previous reports mentioned (Ahmed et al. 1998; NACA, 2002; Hori et al. 2006) almost all rural villagers including farmers conduct fishing. According the results of Hori et al. (2006), fish yields by farmers are comparable amount to that by fishermen. And low agricultural productivity in paddy field is in the background of farmer's fishing (Hori et al. 2006). In Svay Ear and Srey Rangit villages in Kompong Thom province, almost all villages were farmers but more than $85 \%$ of them conducted fishing in order to generate incomes for purchase house consuming rice. They are cultivating rice but their crop yields are not enough for their domestic consumptions. In rural area, there is no job for farmers except fishing. Although the villagers are farmers, they cannot live without fisheries income. Therefore, elaboration of farmers' fishing would be indispensable to grasp exact figures of fishing activities and its importance.

Third issue for fisheries management is little biological knowledge of fish. In case geographically distant populations of a species represent genetically and ecologically distinct stocks, each stock should be treated as a management unit. Elucidate population structure is recognized as a fundamental request for rational resource management (Shepherd, 2004). However, migratory species is believed to be a single stock because it migrate a long distance annually. And few biological studies have been conducted to elucidate exact population structure. Takagi et al. (2006) showed genetic evidence of plural geographically distinct stocks of Bronze featherback Notpterus notopterus using mtDNA analysis in Mekong Basin including Tonle Sap Lake. Similar population structure is assumable for other species, and further population studies would be required for managements. In this context, utilization of local ecological and biological knowledge should be taken account as a methodology. Mekong Basin is famous for its high biodiversity in fauna and flora. It is quite difficult to conduct detailed population study of all species using genetic and/or morphological analyses. However, people around Mekong River have lived with many natural resources over the long term, they have a lot of local knowledge which would be quite useful for sustainable exploitation of natural resources. Therefore, harmonizing scientific and local historical knowledge regarding natural resources will be an excellent way for developing area.

Recently, over exploitation and aggravated fisheries resources are great concern of fisheries management (Sopha et al. 2003). Increase of fishing pressure on resources accompanying population increase would be inevitable without providing other income sources for rural people. Therefore, comprehensive approaches including other sectors, e.g. agriculture and manufacturing industry etc, are required for sustainable development of fisheries.

Negative impact on natural resources from hydrological changes, including dam constrictions should be taken account into development plan and resource managements (Marmulla, 2001). Enomoto et al. (2005) mentioned that hydrologic changes including water level at Mekong River and Tonle Sap Lake can drastically affected on fish stock magnitudes, especially Cyprinidae species. Decline of fish stocks might be derived not from over excessive fishing efforts but from changes of hydrologic environmental conditions. Then, infrastructures should be involved into natural resource managements, even though several construction plans will be called off.

\section{CONCLUSION}

After the French colonial period, Cambodian society and politics have been taunted by speculations of the surrounding and the Eastern counties. And developments of the country are owing to foreign supports. International consensus and world opinions for conservations and developments still have much influence on Cambodian society. But trade-off relationship between development 


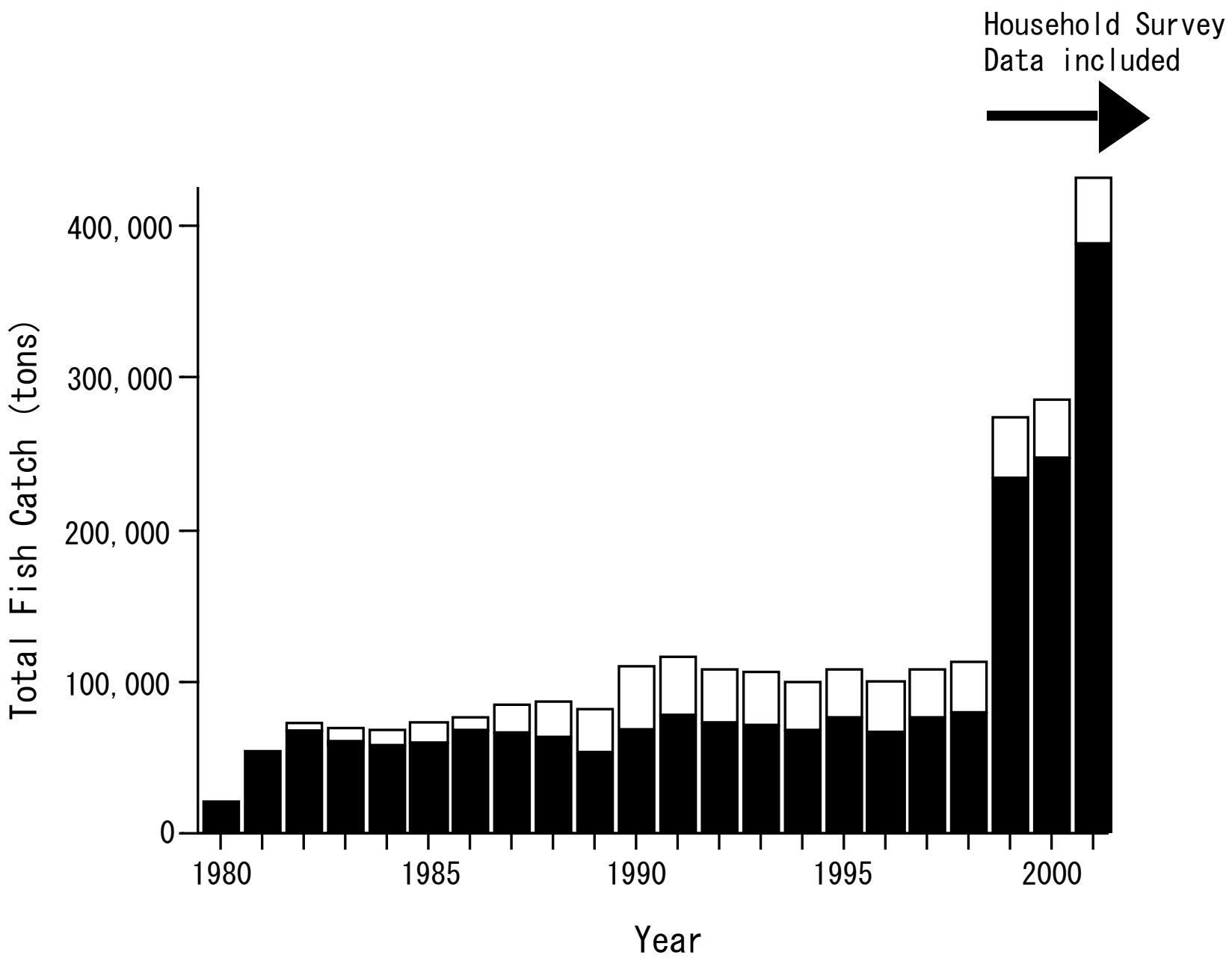

Fig. 4. Time series of fish catches in Cambodia. Black columns indicate fish catch from inland capture fisheries, white columns indicate that from marine capture fishery. Black arrow shows when the data of household survey conducted by MRC and DOF included into fishery statistics (Ahmed et al. 1998)

and conservation sometimes exists. If development goes towards actually poverty eradication, managements should keep high feasibility. In this context, a holistic approach concerning capabilities and functioning is necessary for fundamental goal of the development (Sen, 1992).

ACKNOWLEDGEMENTS The authors thank Dr. Ly Sina and Dr. Somony Thay, Department of Fisheries, Kingdom of Cambodia for their kind help of our study. This study was supported by CREST program of the Japan Science and Technology Agency.

\section{REFERENCES}

Ahmed, M., Navy, H., Vuthy, L. \& Tiongco, M. 1998. Socioeconomic assessment of freshwater capture fisheries in Cambodia: Report on a household survey. Mekong River Commission, Phnom Penh, Cambodia, $1-186$.

Deap, L., Degen, P. \& van Zalinge, N. 2003. Fishing gears of the Cambodian Mekong. Inland fisheries research and development institute of Cambodia, Phnom Penh. Cambodia fisheries technical paper series 4: 1-269, Phom Pehn.

DoF. 2003. Cambodian fisheries annual report. 1-66, Phom Penh.

Ear, S. 1995. Cambodia's economic development in historical perspective. A contribution to the study of Cambodia's economy 1-15.

Enomoto, K., Ishikawa, S., Sitha, H., Thuok, N. \& Kurokura, H. 2005. Relationship between fluctuation of water level and fish catches of Henicorhynchus spp and Chhana microleptes in Kompong Thom 
province, Proceeding of International symposium on sustainable development in the Mekong River Basin, Ho Chi Minh City, Vietnam.

FAO. 1995. Code of conduct for responsible fisheries. $1-65$.

FAO. 2001. International plan of action to prevent, deter and eliminate illegal, unreported and unregulated fishing.

Hori, M., Ishikawa, S., Heng, P., Thay, S., Ly, V., Nao, T., \& Kurokura, H. 2006. Role of small scale fishing in Kompong Thom province, Cambodia, Fisheries Science 72: 846-854.

Mak, S. 2000. Fishing conflict in Battambang province. $1-6$.

Marumulla, G.. 2001. Dams, fish and fisheries. FAO Fisheries Technical Paper 419: 1-166.

Mckenny, B \& Tola, P. 2002. Natural resource and rural livelihood in Cambodia: a baseline assessment. Working paper 23 of Cambodia Development Resource Institute.

Mouhot, H. 1868. Travel in Siam, Cambodia, Laos and Annam, White Lotus, Bangkok.

Tana, T.S. 1998. Management of wetland fisheries in historical perspective of Cambodia.

Thay, S. 2002. Concept of fisheries co-management in Cambodia context: a case study in fishing lot No.3 and No.6, Siem Reap province, Cambodia, Royal Agricultural College.

NACA. 2002. A livelihoods study of farmers and fishers in Dang Tong Village, Kompong Chhnang province. $1-29$.

Sen, A. 1992. Inequality reexamined. Oxford University Press, Oxford.

Shepherd, G. 2004. The ecosystem approach: five steps to implementation. IUCN, Gland, Switzerland and Cambridge.

Sina, L. 2004. The Socioeconomic analysis of Cambodia' $\mathrm{s}$ inland fisheries and the application of fisheries co-management concept. Ph.D Thesis of Graduate School of Science and Technology, Nagasaki University.

Sopha, L., van Zalinge, N. \& Thuok, N. 2003. The need for improvement valuation of Cambodia's wetland fisheries. Wetland Management in Cambodia; Socioeconomic, ecological and policy perspectives. World Fish Center.

Takagi, A., Ishikawa, S., Nao, T., Hort, S., Nakatani, M., Nishida, M. \& Kurokura, H. 2006. Genetic differentiation of the bronze featherback Notopterus notopterus between Mekong River and Tonle Sap
Lake Populations by mitochondrial DNA analysis. Fisheries Science 72: 750-754.

Received $3^{\text {rd }}$ Aug. 2007

Accepted $2^{\text {nd }}$ Aug. 2008 